\title{
Factors Affecting the Risk-taking Behavior of Commercial Banks in Bangladesh
}

\author{
Mohammad Morshedur Rahman ${ }^{1,2}$, Kazi Mohammed Kamal Uddin ${ }^{3}$, Syed Moudud-Ul-Huq ${ }^{4}$ \\ ${ }^{1}$ School of Management, Huazhong University of Science and Technology, Wuhan, Hubei, P. R. China. \\ ${ }^{2}$ Department of Accounting and Information Systems, University of Chittagong, Chittagong, Bangladesh. \\ ${ }^{3}$ Department of Economics, Comilla University, Comilla, Bangladesh. \\ ${ }^{4}$ Department of Business Administration, Mawlana Bhashani Science and Technology University, Santosh, Tangail, \\ Bangladesh \\ Correspondence: Mohammad Morshedur Rahman, School of Management, Huazhong University of Science and \\ Technology, Wuhan, Hubei, P. R. China.
}

Received: June 2, 2015

doi:10.11114/afa.v1i2.850
Accepted: June 16, 2015

Available online: June 25, 2015

\begin{abstract}
This study examines the capital regulation, profitability, bank size, liquidity, off-balance sheet activities, charter value, dividend payout ratio and macroeconomic variables as determinants of bank risk (credit risk and overall risk) by using information from 30 Bangladeshi commercial banks over a period of 2005-2013. We use Generalized Methods of Moments (GMM) in an unbalanced dynamic panel data framework. The empirical results show a negative relation between credit risk and capital regulation and a mixed relation between overall risk and capital regulation. We find a negative relation between credit risk and profitability and a positive relation between overall risk and profitability. The results also show that larger banks take higher credit and overall risk. It is also evident that off-balance sheet activities are positively related with both credit and overall risk. We also find that banks with high liquidity take more credit risk. Negative association is found between credit risk and charter value and mixed evidence is found on the relationship between charter value and overall risk. We also observe that dividend payout ratio is not an important factor of bank risk. With regard to the impact of macroeconomic variables we find no significant impact on risk. Finally we find that lagged risk is an important determinant of bank risk.
\end{abstract}

Keywords: risk-taking, capital regulation, bank Size, off-balance sheet activities, bank, profitability, Bangladesh

\section{Introduction}

Due to global financial crisis during 2007-2008, focus has been given to the consequences that banking system failure may have on an economy (Agnello \& Sousa, 2011). The crisis highlighted the necessity of bank regulation to mitigate the risk taking by banks. The unstable nature of banking and tendency of taking more risk are reflected by recent banking crisis (Haq \& Heaney, 2012). A package of proposals, which are designed to give strength to the liquidity and capital regulation for promoting a higher flexible banking industry, from the Basel Committee are approved by the G-20. Therefore, it is a concern for the academics to explore the determinants of bank risk which are very important for the maintenance of financial stability.

As banking system plays a vital role in economies based on modern market, it is surprising that researches on determinants of risk are still very few. In this study, we examine the impact of various bank-level variables as well as macroeconomic variables on bank overall risk and credit risk. For a number of financial participants, it is very important to understand the risk of bank. The evaluation of risk of bank is important for the stakeholders such as regulators, government, borrowers, market supervisors, bondholders and shareholders. As regulators and supervisors are responsible for financial stability, they have an interest on bank overall risk. Bondholders are concerned about the probability of bank default and concerned about the overall risk and shareholders are concerned about the systematic risk and overall risk. Usually borrowers are concerned about the financial health of banks for credit, so they are interested in credit risk (Haq \& Heaney, 2012).

A banking risk may vary following bank-level variables (Haq \& Heaney, 2012) such as capital regulation, charter value, 
bank size, dividend payout, off-balance sheet activities (non-interest generating items). It may also vary following macroeconomic variables (Festić, Kavkler, \& Repina, 2011; Louzis, Vouldis, \& Metaxes, 2012; Nkusu, 2011) such as a change in growth, unemployment, inflation and interest rates. Llewellyn (2002) focused on some other issues, for example, problems in banking system derived from structural weaknesses in the economy and the financial system, incentive structures, hazardous banking practices, and moral hazard. A banking risk is generally created by inability of banks to pay payments when they become due. As banking sector is rapidly growing in Bangladesh, it is important to analysis the bank risk. With the increased number of banks and their sizes, it is now necessary to focus on the factors of bank risk as large banks will become 'too large to fail' (Haq \& Heaney, 2012).

This study contributes to the existing literature of bank risk in many ways. First, this is the first empirical paper to explore the determinants of bank risk-taking in Bangladesh. Second, we focus on a comparative study of all the determinants that affect banking credit and overall risk whereas the literature mostly focus on credit risk, for example Chaibi and Ftiti (2015). The objective of our paper is to identify the most important bank-level and macroeconomic determinants of bank overall and credit risk. In term of methodology, we apply the generalized method of moments (GMM) system estimator developed by the Arellano and Bover (1995) and the Blundell and Bond (1998) to consider potential both serial correlation and endogenity problems.

The structure of the remainder of the paper is as follows. Section 2 focuses on the relevant literature and hypotheses. Section 3 represents the data and variables. Section 4 presents the econometric model. Section 5 discusses on the empirical results. Finally section 6 concludes the paper with suggestions to the stakeholders.

\section{Literature Review and Hypotheses Development}

In the context of literature survey, the selected previous literatures relating to the determinants of bank risk have been divided into two brought categories: bank-level specific determinants affecting credit risk and overall risk, and macroeconomic determinants affecting credit risk and overall risk. Financial crises in Europe explore the necessity of the better examination of determinants of bank risk in the worldwide. This is also very important in Bangladesh, because banking sector in Bangladesh is growing rapidly in recent years having a huge competition among them. Regulators have made a lot of regulations in accordance with the rules of BASEL I, II and III. The probability of shifting of risk and the costs for the failure of banks to the society are considered as proper justification of regulation of the banking system (Haq \& Heaney, 2012). Along with other factors, capital regulation and charter value have impact on risk taking behavior of banks (Park \& Peristiani, 2007). Thus we focus on the literature of the determinants of credit and overall risk.

\subsection{Capital Regulation}

According to Basle Capital Accord banks have to maintain capital on the basis of risk-weighted assets. In Bangladesh, BASEL I was introduced in 1996, BASEL II was introduced in 2007 with an expectation that the requirements for regulatory capital would increase the stability of management of commercial banks. Theoretically the impact of BASEL capital requirements on risk taking behavior of banks is ambiguous. Higher capital requirements may have positive impact on risk of commercial banks (Lee \& Chih, 2013). But the empirical results show both positive and negative impacts of regulatory capital on risk. Some studies found positive impact of capital on risk (Altunbas, Carbo, Gardener, \& Molyneux, 2007; Blum, 1999; Kahane, 1977; Kim \& Santomero, 1988; Koehn \& Santomero, 1980; Laeven \& Levine, 2009; Lin, Penm, Gong, \& Chang, 2005; Rime, 2001; Shrieves \& Dahl, 1992). On the contrary, some other studies found negative impact of capital on risk (Agoraki, Delis, \& Pasiouras, 2011; Ho \& Hsu, 2010; Jacques \& Nigro, 1997; Lee \& Chih, 2013; Z.-y. Zhang, Wu, \& Liu, 2008). Calem and Rob (1999) and Iwatsubo (2007) found mixed results.

\subsection{Bank Size}

Bank size is considered as an important determinant of bank risk-taking behavior. Large banks can carry out a different variety of activities, as a result they can easily diversify their portfolio, and hence risk will be decreased (Roy, 2008). Jacques and Nigro (1997) found that bank size has a significant positive impact on bank risk. Similar relationship is also found by Altunbas et al. (2007); González (2005); Hussain and Hassan (2005); Jokipii and Milne (2011); Klomp and Haan (2012); Rime (2001); Roy (2008); Z.-y. Zhang et al. (2008). Negative impact of size on risk is found by Aggarwal and Jacques (1998); Laeven and Levine (2009).

\subsection{Profitability}

Profitability is also considered as an important factor of bank risk. But very few studies in the literature consider the profitability as a factor of risk. Findings of Kwan and Eisenbeis (1997) support the hypothesis of moral hazard which means that banks with high profitability are less vulnerable than banks with low profitability. There is a negative significance impact of profitability on risk (Lin et al., 2005; J. Zhang, Jiang, Qu, \& Wang, 2013). Some studies found positive impact of profitability on risk (Mamatzakis \& Bermpei, 2014; Naceur \& Omran, 2011). 


\subsection{Liquidity}

In the literature of risk of banks, liquidity is considered as an important one. A major portion of total assets corresponds to loans and advances. High level of liquidity is represented by high level of loans and advances which means there is a high level investment in risk-weighted assets. Therefore, it will lead the banks to a high level of risk (Berger, 1995; Roy, 2008). A high level of the liquidity ratio represents a low level of liquidity which implies that there is a risk for not having enough cash reserves in the banks to meet the demands of deposit withdrawals.

\subsection{Off-balance Sheet Activities}

For imposing more regulations and for increasing competition in banks, non-traditional activities are increasing which are to create contingent assets and liabilities (Haq \& Heaney, 2012). The off-balance sheet activities are the contingent liabilities of the banks which includes the guarantees by banks for commercial letters of credit and loan commitments. Off-balance sheet activities help banks to increase their revenue sources without changing the capital structure (Deelchand \& Padgett, 2009). Mixed results are found from the literature about the impact of off-balance sheet activities on risk. There is a negative relationship between off-balance sheet activities and risk (Hassan, Karels, \& Peterson, 1994). Positive relation between off-balance sheet activities and risk is found in some studies (Angbazo, 1997; Fraser, Madura, \& Weigand, 2002; Wagster, 1996).

\subsection{Charter Value}

There is a debate that the charter value of banks eases the problem of moral hazard which is arisen from too-big-to-fail, deposit insurance and limited liability effect (Haq \& Heaney, 2012). According to Park and Peristiani (2007), banks like to avoid risk for protecting charter values. Empirical evidence show that there is a positive relation between charter value and bank risk (Saunders \& Wilson, 2001). There are also studies that support the negative relationship between charter value and risk (Anderson \& Fraser, 2000; Konishi \& Yasuda, 2004). Haq and Heaney (2012) found mixed evidence in the relationship between risk and charter value. We expect a negative relationship between charter value and bank risk.

\subsection{Dividend Pay-Out Ratio}

Dividend pay-out policy is considered as a costly signal for the solvency of a bank (Bessler \& Nohel, 1996). As a result banks can decrease the information asymmetry costs and there may be a tendency to decrease the dividends as a measure for last remedy. It is assumed from the literature that dividends can make stronger the problem of moral hazard. There is a possibility for default if banks pay excessive dividends. To meet the demands, banks may have a tendency to realize their safer assets. As a result, riskier assets will be kept in the bank (Acharya, Gujral, Kulkarni, \& Shin, 2011).

\subsection{Growth in real Gross Domestic Product (GDP)}

Total activities of an economy are measured by the GDP. Credit risk choices of banks may be affected by the growth in GDP (GGDP) for changing the structure or the volume of loan demand (Cihák \& Schaeck, 2007; Hussain \& Hassan, 2005). Ayuso, Pérez, and Saurina (2004) and Jiménez and Saurina (2006) pointed that the credit risk have a tendency to be determined due to cyclical factors. It is assumed to have a positive impact of GGDP on bank risk.

\subsection{Inflation}

Inflation, as a macroeconomic factor which shows the macro-economic condition of an economy, has an important impact on bank risk. Positive association between inflation and risk is found in literature, for example, Hussain and Hassan (2005).

\subsection{Ownership Structure}

In the previous study, ownership structure is considered as an important factor of bank risk taking. Ownership structure affects the principle-agent relationship which influences risk taking behavior of banks (Agusman, Cullen, Gasbarro, Monroe, \& Zumwalt, 2014; Boubakri, Cosset, \& Saffar, 2013; Iannotta, Nocera, \& Sironi, 2013; Levine, Caprio, \& Barth, 1999).

\subsection{Concentration}

In the literature of determinants of risk, concentration is also considered as a determinant of risk to count the competition among the banks. High concentration ratio indicates the low level of competition. Boyd and De Nicoló (2005) argued that charter value of banks is to be deteriorated due to increase in competition which is harmful for the stability of financial system and therefore, banks are encouraged to take more risk. On the other hand, Beck, Demirgüç-Kunt, and Levine (2006) show that systematic risk is lower for concentrated banking system and the system will be more stable over time.

Based on the above variables description and literature following three hypotheses are developed. 
Hypothesis 1. Bank specific factors namely capital regulation, bank size, profitability, charter value decrease the level of bank risk taking and on the opposite to this bank specific factors namely liquidity, off-balance sheet activities, dividend policy increase the level of bank risk taking.

Hypothesis 2. Industry specific factors namely concentration increases the level of bank risk taking and ownership structure has a significant impact on the level of bank risk taking.

Hypothesis 3. Macroeconomic factors namely GGDP and inflation increase the level of bank risk taking.

\section{Data and Variables}

There are 57 commercial banks working in Bangladesh at the end of 2014, of which 39 banks are private-owned banks, 4 banks are state-owned banks, 9 banks are foreign-owned banks, and 5 banks are state-owned development financial institutions. Government, private investors, foreign investors and government are the owner of state-owned, private-owned, foreign-owned banks, and state-owned development financial institutions respectively. Development financial institutions are not commercial banks rather they are used for special activities.

The objective of this paper is to identify the important determinants of bank risk in Bangladesh. According to previous literature, we use two types of variables: bank-level and macroeconomic variables. Bank-level variables are collected from the balance sheet and income statement as well as website of selected banks. The initial sample consists of 57 banks. We exclude 15 commercial banks from the sample as they are new. 5 specialized banks are also excluded from the sample, as they do not run for commercial purpose. We also exclude 7 foreign banks from our sample for unavailability of data. Finally the data is composed of selected 30 Bangladeshi commercial banks covering a period of 2005-2013 As the information for all banks are not available for all years, we use an unbalanced panel data for not losing degrees of freedom. Thus samples composed of 30 banks in Bangladesh.

We have obtained the data for micro economic variables from the website of Bangladesh Bank (http://www.bangladesh-bank.org) as well as the database of World Bank (http://data.worldbank.org). The selected variables that affect the bank risk are based on previous literature and theory. We present the variables used for our study in the Table 1.

Table 1. Description of the Variables

\begin{tabular}{|c|c|c|c|}
\hline \multicolumn{2}{|c|}{ Variables } & Symbol & \multirow{2}{*}{$\begin{array}{l}\text { Definition } \\
\text { Ratio of nonperforming loans to total loans }\end{array}$} \\
\hline & Credit risk & NPLTL (RISK) & \\
\hline \multirow[t]{3}{*}{ Risk } & Overall risk & SROA (RISK) & Standard deviation of return on assets (Volatility in ROA) \\
\hline & Overall risk & SROE (RISK) & Standard deviation of return on equity (Volatility in ROE) \\
\hline & Credit risk & LLPTL (RISK) & Ratio of loan loss provisions to total loans \\
\hline \multicolumn{2}{|c|}{ Capital Regulation } & CAP & $\begin{array}{l}\text { Regulatory capital to risk weighted assets, i.e. Capital } \\
\text { Adequacy Ratio (CAR) }\end{array}$ \\
\hline \multicolumn{2}{|c|}{ Bank Size } & SIZE & Natural logarithm of total assets \\
\hline \multicolumn{2}{|c|}{ Profitability } & PROF & Return on Assets (ROA) \\
\hline \multicolumn{2}{|c|}{ Liquidity } & LIQUIDITY & Ratio of total loans to total deposits \\
\hline \multicolumn{2}{|c|}{ Off-balance sheet activities } & OFBSTL & $\begin{array}{l}\text { Ratio of off balance sheet items to total liabilities (includes } \\
\text { contingent liabilities such as loan commitments, standby letters } \\
\text { of credit, banker's acceptance and guarantees as well as } \\
\text { derivatives, swaps, options and futures) }\end{array}$ \\
\hline \multicolumn{2}{|c|}{ Charter Value } & CVALUE & $\begin{array}{l}\text { Market value of equity plus book value of liabilities divided by } \\
\text { book value of total assets }\end{array}$ \\
\hline \multicolumn{2}{|c|}{ Dividend-payout ratio } & DPR & Cash dividend divided by net income \\
\hline \multicolumn{2}{|c|}{ Growth in real GDP } & GGDP & Annual growth in real gross domestic product \\
\hline \multicolumn{2}{|c|}{ Inflation rate } & INFR & Annual inflation rate \\
\hline \multicolumn{2}{|c|}{ Ownership Structure } & OWNS & $\begin{array}{l}\text { Equals } 1 \text { if the banks is a private commercial bank and zero for } \\
\text { otherwise }\end{array}$ \\
\hline \multicolumn{2}{|c|}{ Concentration } & CONC & Assets of three largest banks as a share of assets of all banks \\
\hline
\end{tabular}

The risk variables used as RISK in the following section has two measures of credit risk and two measures of overall risk. Two measures of credit risk are: the ratio of non-performing loans to total loans (NPLTL) and the loan loss provisions to total loans (LLPTL). Two measures of overall risk are: standard deviation of return on assets (SROA) and standard deviation of return on equity (SROE). Capital to risk weighted assets is used as a proxy for capital regulation (CAP). In Bangladesh, bank has to maintain a capital of $10 \%$ or taka 4000 million which one is higher. For potential size effect we include the bank size (SIZE) which is measured by the natural logarithm of total assets. Profitability is 
negatively related with enhances in bad loans in future (Chaibi \& Ftiti, 2015). We include profitability (PROF) in the list of determinant to show effect of profitability on risk and we measure this factor as the return on total assets.

We include liquidity (LIQUIDITY) to show whether there is a risk in the bank for not having enough cash reserves to meet the demands of deposit withdrawals. We measure this variable by the ratio of total loans to total deposits. Off-balance sheet activities are included to show the effect of non-traditional activities and are proxied by the ratio of total off-balance sheet activities to total liabilities (OFBSTL). Following Keeley (1990) and Haq and Heaney (2012) we use the charter value (CVALUE) as the market value of equity plus the book value of liabilities divided by the book value of total assets. Dividend payout ratio (DPR) is proxied by the ratio of cash dividend and net earnings. Due to political and other influence in Bangladesh, ownership structure (OWNS) plays a vital role in the risk taking behavior of banks. To capture this we include ownership structure dummy variable as a factor of bank risk. Ownership structure equals 1 if the bank is a privately owned bank and 0 for otherwise. Bank concentration (CONC) is also included to control for the concentration of banks. The ratio of the total assets of three largest banks to total assets of all banks in banking industry is used as a proxy for bank concentration. To capture macro-economic impact on bank risk we use GGDP and annual inflation (INFR) rate as proxy for economic growth and inflation.

\section{Econometric Model}

The empirical model to test our hypothesis for the determinants of bank risk as given below:

$$
\begin{gathered}
\text { RISK }_{\mathrm{it}}=\alpha+\beta_{1} \mathrm{CAP}_{\mathrm{it}}+\beta_{2} \text { SIZE }_{\mathrm{it}}+\beta_{3} \text { PROF }_{\mathrm{it}}+\beta_{4} \text { LIQUIDITY }_{\mathrm{it}}+\beta_{5} \text { OFBSTL }_{\mathrm{it}}+\beta_{6} \text { CVALUE }_{\mathrm{t}}+\beta_{7} \text { DPR }_{\mathrm{it}}+ \\
\beta_{8} \mathrm{GGDP}_{\mathrm{t}}+\beta_{9} \mathrm{INFR}_{\mathrm{t}}+\beta_{10} \mathrm{ONWS}_{\mathrm{i}}+\beta_{11} \mathrm{CONC}_{\mathrm{t}}+\varepsilon_{\mathrm{it}}
\end{gathered}
$$

Where the $\mathrm{i}$ subscript denotes the cross-sectional dimension across banks $(\mathrm{i}=1,2, \ldots \ldots ., 30)$, and $\mathrm{t}$ denotes the time dimension $(t=2005,2006, \ldots \ldots . ., 2013)$. The remaining disturbance term is reported by $\varepsilon$. As stated earlier we use RISK as the variable for bank's risk. Our main risk measure is NPLTL which is referred as credit risk. We use another one alternative measure for credit risk namely LLPTL. A high level of ratio indicates a high level of risk. We use two alternative measures for overall risk. They are: (i) Volatility in ROA (SROA), (ii) Volatility in ROE (SROE). The volatility of ROE and ROA is measured as the standard deviation of ROE and ROA respectively. A high value of standard deviation of ROE and ROA also shows high level of risk.

CAP is the proxy for capital regulation for banks and we use Capital Adequacy Ratio (CAR) as the measure for capital regulation. Return on Assets (ROA) is used as a proxy for bank profitability (PROF).

We use SIZE, LIQUIDITY, OFBSTL, CVALUE, DPR, OWNS, CONC for bank-level determinants and GGDP, INFR as macroeconomic factors which are assumed as important determinants of bank risk. The definition of the variables used in regression equation (1) is as mentioned in section 4 and also as presented in Table 1. We regress the credit and overall risk measures on the above bank-specific, industry-specific and macroeconomic variables. GMM system estimator developed by the Arellano and Bover (1995) and the Blundell and Bond (1998) to consider potential both serial correlation and endogenity problems.

\section{Empirical Results}

Empirical discussion is presented in three parts. The descriptive statistics of all variables both dependent and independent are presented in part 1. Correlations among the variables are depicted in part 2 and regression analysis is explored in part 3.

\subsection{Descriptive Statistics}

Descriptive statistics of all variables are presented in following Table 2. Our main risk variable is NPLTL. We also use three alternative measures for risk proxied by LLPTL, SROA, and SROE. From the Table 2 it is seen that the average credit risk measured by NPLTL and LLPTL are $5.39522 \%$ and $2.72875 \%$ respectively. The NPLTL ranges from a maximum $44.5913 \%$ to a minimum $0.193349 \%$ with a standard deviation of 6.35338 . On the other hand, the LLPTL ranges from a maximum $27.50658 \%$ to a minimum $0 \%$ with a standard deviation of 4.53431 .

It is also observed from the table that the average credit risks proxied by SROA and SROE are 0.87658 and 13.7451 respectively. The maximum and minimum values of SROA are 3.91220 and 0.27500 respectively. SROE ranges from a maximum 120.948 to a minimum 1.83190. The standard deviation for SROA and SROE is 0.78891 and 21.7155 respectively. The table also shows that the average CAR is $11.13466 \%$ which is higher than the required minimum in Bangladesh. According to the capital regulation, the banks in Bangladesh have to maintain a capital which is 10\% of risk weighted assets or TK 4000 million which one is higher as minimum capital requirements. CAR ranges from a maximum $16.84 \%$ to a minimum $-6.01 \%$. 
Table 2. Descriptive Statistics of all Variables

\begin{tabular}{llccccc}
\hline & Mean & Median & Maximum & Minimum & Std. Dev. & Observations \\
\hline NPLTL $(\%)$ & 5.39522 & 3.55992 & 44.5913 & 0.193349 & 6.35338 & 182 \\
LLPTL $(\%)$ & 2.72875 & 1.30582 & 27.5065 & 0.00000 & 4.53431 & 182 \\
SROA & 0.87658 & 0.65030 & 3.91220 & 0.27500 & 0.78891 & 182 \\
SROE & 13.7451 & 7.68380 & 120.948 & 1.83190 & 21.7155 & 182 \\
CAR (\%) & 11.1346 & 11.2550 & 16.8400 & -6.01000 & 2.60613 & 182 \\
SIZE & 11.4629 & 11.4525 & 13.6556 & 9.91130 & 0.78955 & 182 \\
ROA $(\%)$ & 1.33511 & 1.42500 & 3.5400 & -10.2800 & 1.31782 & 182 \\
LIQUIDITY $(\%)$ & 82.7714 & 83.1296 & 108.258 & 50.0733 & 10.4540 & 182 \\
OFBSTL $(\%)$ & 29.6496 & 29.4478 & 73.1419 & 2.98169 & 11.1958 & 182 \\
CVALUE & 1.09670 & 1.05892 & 2.70009 & 0.55189 & 0.19636 & 182 \\
DPR $(\%)$ & 3.37634 & 0.00000 & 36.3557 & 0.00000 & 7.08280 & 182 \\
GGDP $(\%)$ & 6.24098 & 6.19000 & 6.70000 & 5.74000 & 0.30257 & 182 \\
INFR (\%) & 8.19659 & 7.70000 & 10.6200 & 6.66000 & 1.36992 & 182 \\
OWND & 0.88461 & 1.00000 & 1.00000 & 0.00000 & 0.32036 & 182 \\
CONC $(\%)$ & 30.5481 & 31.2931 & 34.4624 & 23.3902 & 3.18906 & 182 \\
\hline
\end{tabular}

Average profitability of banks is $1.33511 \%$ and profitability ranges from a maximum $3.54 \%$ to a minimum $-10.28 \%$ with a standard deviation of 1.317829. The average value, maximum, minimum and standard deviation with median of SIZE, LIQUIDITY, OFBSTL, CVALUE, DPR, GGDP, INFR, OWND and CONC are also presented in Table 2 above.

\subsection{Correlation Analysis}

Pearson's correlation coefficients between variables are presented in Table 3. The main objective of this paper is to identify the main determinants of risk-taking behavior of banks in Bangladesh. From the Table 3 it is seen that CAR is negatively and significantly related with both credit and overall risk which implies that as regulatory capital increases the credit and overall risk-taking by banks decrease.

Table 3. Pearson's Correlation Coefficients between variables

\begin{tabular}{|c|c|c|c|c|c|c|c|c|c|c|c|c|c|c|c|}
\hline & NPLTL & LLPTL & SROA & SROE & CAR & SIZE & PROF & $\begin{array}{l}\text { LIQUIDI } \\
\text { TY }\end{array}$ & $\begin{array}{l}\text { OFBST } \\
\text { A }\end{array}$ & $\begin{array}{l}\text { CVAL } \\
\text { UE }\end{array}$ & DPR & GGDP & INFR & $\begin{array}{l}\text { OW } \\
\text { ND }\end{array}$ & $\begin{array}{l}\mathrm{CO} \\
\mathrm{NC}\end{array}$ \\
\hline NPLTL & 1 & & & & & & & & & & & & & & \\
\hline LLPTL & $.960^{+* * *}$ & 1 & & & & & & & & & & & & & \\
\hline SROA & $.879^{\circ * *}$ & $.897^{* * *}$ & 1 & & & & & & & & & & & & \\
\hline SROE & $.634^{4 * *}$ & $.545^{* * *}$ & $.709^{* * * *}$ & 1 & & & & & & & & & & & \\
\hline CAR & $-.397^{* * *}$ & $-.357^{* * *}$ & $-.370^{n+*}$ & $-.402^{\ldots+\cdots}$ & 1 & & & & & & & & & & \\
\hline SIZE & $.594^{4 * *}$ & $.607^{+* * *}$ & $.622^{+* * *}$ & $.453^{\cdots+*}$ & $-.268^{*+*}$ & 1 & & & & & & & & & \\
\hline PROF & $-.547^{* * * *}$ & $-.526^{* t *}$ & $-.456^{* * *}$ & $-.328^{* \ldots *}$ & $.644^{4 * 0 *}$ & $-.321^{*+*}$ & 1 & & & & & & & & \\
\hline $\begin{array}{l}\text { LIQUIDI } \\
\text { TY }\end{array}$ & $-.529^{* * *}$ & $-.502^{* * *}$ & $-.498^{* * *}$ & $-.367^{\ldots * *}$ & $.206^{\circ+*}$ & $-.435^{* * *}$ & $.313^{+* * *}$ & 1 & & & & & & & \\
\hline OFBSTA & $-.251^{* * * *}$ & $-247^{* \ldots *}$ & $-.197^{* * *}$ & -.102 & -.069 & -.106 & $.180^{\circ *}$ & $.204^{* * *}$ & 1 & & & & & & \\
\hline CVALUE & $-.246 *$ & $-.192^{* * * *}$ & $-.189^{* *}$ & $-.208^{* \ldots * *}$ & .016 & $-.271^{* * *}$ & $.152^{* *}$ & $.195^{* * *+}$ & $.212^{*+*}$ & 1 & & & & & \\
\hline DPR & -.089 & $-.132^{*}$ & $-.135^{*}$ & $-.139^{*}$ & .087 & .109 & .046 & -.032 & .013 & -.088 & 1 & & & & \\
\hline GGDP & -.050 & -.060 & -.027 & -.050 & -.091 & $-.189^{* *}$ & -.104 & .094 & $.139 *$ & -.053 & .084 & 1 & & & \\
\hline INFR & .079 & .052 & .021 & .040 & -.051 & $.273^{* * *}$ & $-.194^{\prime \cdots *}$ & .001 & -.096 & $-.128^{\circ}$ & .078 & $.214^{* \ldots+}$ & 1 & & \\
\hline OWND & $-.816^{* * * *}$ & $-.805^{* \ldots *}$ & $-.881^{* * *}$ & $-.778^{\ldots+*}$ & $.412^{\ldots \cdots}$ & $-.650^{*+*+}$ & $.450^{\circ *}$ & $.521^{* * *}$ & $.130^{\circ}$ & $.152^{* *}$ & .097 & .044 & -.031 & 1 & \\
\hline $\mathrm{CONC}$ & .063 & .050 & .031 & .049 & $.262 \cdots$ & $.159^{* *}$ & .092 & -.036 & $-.238^{* * *+}$ & -.067 & .056 & $-319^{* * *}$ & $.248^{\circ * *}$ & -.057 & 1 \\
\hline
\end{tabular}

Note: $* * *, * *$, and $*$ indicate significance at $1 \%, 5 \%$ and $10 \%$ respectively.

It is also revealed from the table that bank size is positively and significantly related with both credit and overall risk which implies that large banks take more risk. PROF is negatively and significantly related with risk for all four measures which suggests that banks with low profitability take high level of risks. LIQUIDITY has a negative and significant impact on credit and overall risk. The negative sign implies that liquid banks take low level of risk. OFBSTA, CVALUE and OWND dummy have significant and negative impact on risk. The negative sign of ownership dummy 
suggests that private commercial banks take a level of risk which is lower than that of state-owned banks.

GGDP has negative but insignificant impact on risk which implies that as GGDP increase the risk taking by banks decrease. The impact of INFR and CONC on risk is not statistically significant. It is observed from the correlation that some relations and sign of relationship are ambiguous; therefore we need to run regression analysis.

\subsection{Regression Analysis}

In this study we apply GMM system panel estimator developed by Arellano and Bover (1995) and Blundell and Bond (1998). Table 4 shows the estimated results from GMM estimator. Our main risk variable is NPLTL. We use three other alternatives of risk measures; they are SROA, SROE, and LLPTL. Our main concern is to find out the main determinants of bank risk in Bangladesh. We use both bank internal control variables and macroeconomic variables to see the impact on risk.

From the table it is seen that CAP is negatively and significantly related with credit risk proxied by NPLTL and LLPTL and with overall risk proxied by SROE, but the relation is positive when SROA is used for overall risk. It implies that banks with a high level of CAR take low level of credit and overall risk. PROF is negatively and significantly related with both measures of credit risk and positively related with both measures of overall risk which suggests that banks with a low profitability take high level of credit risk and a low level of overall risk. In opposite to our expectation we find that SIZE has a positive significant impact on both credit and overall risk which implies that large banks take more credit and overall risk.

Table 4. Determinants of Bank Risk

\begin{tabular}{|c|c|c|c|c|}
\hline \multirow[t]{2}{*}{ Variables } & Model 1 & Model 2 & Model 3 & Model 4 \\
\hline & RISK=NPLTL & $\mathrm{RISK}=\mathrm{SROA}$ & RISK=SROE & RISK=LLPTL \\
\hline CAP & $-0.72^{* *}(-2.43)$ & $0.01 *(1.78)$ & $-0.03 *(-1.72)$ & $-0.55^{* * *}(-2.81)$ \\
\hline SIZE & $0.71 * * *(3.25)$ & $0.02 *(1.77)$ & $0.25 * 91.78)$ & $0.33 * *(2.14)$ \\
\hline PROF & $-1.08^{* *}(-2.27)$ & $0.18(0.92)$ & $0.71(1.15)$ & $-0.81 * *(-2.39)$ \\
\hline LIQUIDITY & $0.04 * *(2.23)$ & $0.02(0.82)$ & $-0.02(-0.97)$ & $0.03^{* *}(2.43)$ \\
\hline OFBSTL & $0.05^{* * *}(2.95)$ & $0.04 *(1.68)$ & $0.02 *(1.72)$ & $0.02 * *(2.17)$ \\
\hline CVALUE & $-1.08 *(-1.68)$ & $0.03 *(1.69)$ & $-0.83(-0.89)$ & $-0.09(-0.19)$ \\
\hline DPR & $-0.01(-0.27)$ & $0.02(0.99)$ & $-0.002(-0.88)$ & $-0.01(-0.68)$ \\
\hline GGDP & $0.67(0.58)$ & $-0.005(-0.62)$ & $-0.001(-0.23)$ & $-0.48 *(-1.76)$ \\
\hline INFR & $0.08(0.55)$ & $0.002(0.59)$ & $0.17(0.95)$ & $0.05(0.46)$ \\
\hline OWND & $4.69 *(1.78)$ & $-0.017(-0.39)$ & $-2.32(-0.88)$ & $1.63 *(1.71)$ \\
\hline CONC & $0.13 *(1.77)$ & $-0.003(-0.66)$ & $-0.004(-0.54)$ & $0.11 *(1.69)$ \\
\hline $\operatorname{NPLTL}(-1)$ & $0.55 * * *(7.86)$ & & & \\
\hline $\operatorname{SROA}(-1)$ & & $0.99 * * *(23.75)$ & & \\
\hline SROE (-1) & & & $0.94 * * *(22.42)$ & \\
\hline $\operatorname{LLPTL}(-1)$ & & & & $0.84 * * *(11.24)$ \\
\hline Adjusted $\mathrm{R}^{2}$ & 72.79 & 81.19 & 73.72 & 83.54 \\
\hline Hausman Test, F(p-value) & $17.43(0.000)$ & $20.23(0.000)$ & $19.12(0.000)$ & $22.51(0.000)$ \\
\hline Sargan test (p-value) & 0.342 & 0.354 & 0.441 & 0.273 \\
\hline Serial correlation test ( $\mathrm{p}$-value) & 0.000 & 0.000 & 0.000 & 0.000 \\
\hline Observations & 182 & 182 & 182 & 182 \\
\hline Number of banks & 30 & 30 & 30 & 30 \\
\hline
\end{tabular}

Notes: The table shows the empirical results from GMM panel estimator. Dependent variable is capital for all four models. ***, ** and

* indicate significance at the $1 \%, 5 \%$ and $10 \%$ respectively. For Hausman test p-values are in parentheses. t-statistics are shown in parentheses. (-1) indicates time lag 1.

LIQUIDITY has a positive and significant impact on credit risk and overall risk, but the sign is negative when SROE is used for overall risk. The result implies that banks with high liquidity take more credit and overall risks. OFBSTL has a positive and significant relation with both credit and overall risk which suggest that banks with high involvement in off-balance sheet activities face high level $\mathrm{f}$ risk. It is also seen from the table that CVALUE has a negative relation with 
NPLTL, SROE, LLPTL and a positive relation with SROA. It can be concluded that banks with a high charter value face lower level of risk and the risk is high when SROA is used as a proxy for overall risk.

DPR is negatively related with risk and the relationships are not statistically significant. This is because it is seen from the data that for maintaining the level of CAR most of the banks did not pay cash dividend to their shareholders during study period. GDP and INFR do not have significant impact on risk. OWND is significantly and positively related with NPLTL and LLPTL and negatively related with SROA and SROE which implies that private commercial banks tend to have credit risk that is much higher than comparable state-owned banks and tend to have overall risk that is much lower than comparable state-owned banks. The effect is quantitatively important, indicating that average private-owned bank has a credit risk that is $4.69 \%$ points higher for NPLTL than that of the average state-owned banks and $1.63 \%$ points higher for LLPTL. On the other hand, average private-owned bank has an overall risk that is $2.32 \%$ points lower for SROE and $0.017 \%$ points lower for SROA than that of the average state-owned bank. CONC has a positive and significant impact on credit risk and negative impact on overall risk which suggest that in a concentrated market banks take more credit risk and take low level of overall risk. Finally time lag 1 for all four models shows a significant and positive relation between risk in time $t$ and risk in time $t-1$. This implies that banks with a high level of risk in previous year also take high risk in current year.

In Table 4, the Hausman test implies that the capital and profitability are endogeneous variables in risk equation. The p-value of Sargan test is insignificant for Model 1, 2, 3, and 4 which means that we have valid instruments. From the p-value of serial correlation test we can reject the null hypothesis of no serial correlation. The adjusted R-squared shows that $72.79 \%, 81.19 \%, 73.72 \%$ and $83.54 \%$ variation in risk is explained by the Model 1, 2, 3, and 4 respectively.

\section{Conclusion and Suggestions}

In this paper we develop and test the model for bank risk-taking by including profitability, capital regulation, bank size, liquidity, off-balance sheet activities, charter value, dividend payout ratio, growth in gross domestic product, inflation rate, ownership structure, and concentration, as potential determinants of credit risk and overall risk of Bangladeshi commercial banks. We use a sample of 30 commercial banks from Bangladesh for a period from 2005 to 2013 . The main objective of the paper is to identify the main determinants of risk-taking by commercial banks in Bangladesh. In this direction we have used two types of risks namely credit risk proxied by NPLTL and LLPTL and overall risk proxied by SROA and SROE in our empirical analysis.

Findings suggest that capital is negatively related with credit and overall risk with exception of SROA indicating that reduced risk is resulted by increased bank capital over the period of study. Profitability is also found as an important factor for credit risk-taking. We find a negative and significant relationship between credit risk and profitability, which implies that banks with high profitability take low level of credit risk. The other important determinant of bank risk is bank size. We find a statistically significant positive relationship between risk (credit and overall risk) and bank size, which suggest that large banks take higher risk than that of small banks. Liquidity is found as a statistically significant determinant of credit risk but for overall risk liquidity is not an important determinant and we find a positive relation between credit risk and liquidity which implies that banks with high liquidity take more credit risk.

The empirical results show that off-balance sheet activities are positively and significantly related with both credit and overall risk. Thus, bank risk is increased due to increase in off-balance sheet activities. It is also seen from the empirical result that charter value is an important determinant of bank risk. We find a negative and significant relation between bank risk and charter value but the relation is positive when SROA is used as a proxy for overall risk. Ownership structure is found as a significant factor of bank credit risk. We find a positive and significant relationship between ownership structure dummy and credit risk which implies that private commercial banks tend to have more credit risk that are much higher than comparable state-owned banks.

It is also evident from the empirical results that dividend payout ratio is not an important determinant of bank risk. One possible explanation may be that most of the banks did not pay cash dividend during study period to cover up the requirements of BASEL capital requirements. It is also found from the results that macroeconomic variables (Growth in GDP and annual inflation rate) are not statistically significant determinants for any risk measures. One possible answer could be that macroeconomic impact to all banks within a country is same. To cover the impact of macroeconomic variables cross cultural banks may be considered in future studies. Finally, it is also evident from the empirical results that the lagged values of all four measures of risk are important determinants of risk which implies that banks with higher risk in the last period will take more risk in the current period. Results from our empirical analysis will provide important implications for regulators of banks, government, shareholders, bond holders, and creditors etc. all of whom are related with risk, capital regulation and profitability of commercial banks in Bangladesh. 


\section{References}

Acharya, V. V., Gujral, I., Kulkarni, N., \& Shin, H. S. (2011). Dividends and Bank Capital in the Financial Crisis of 2007-2009. National Bureau of Economic Research, Working Paper, 16896.

Aggarwal, R., \& Jacques, K. T. (1998). Assessing the Impact of Prompt Corrective Action on Bank Capital and Risk. FRBNY Economic Policy Review, 23-32.

Agnello, L., \& Sousa, R. M. (2011). How do Banking Crises Impact on Income Inequality?.pdf. NIPE Working Papers, University of Minho, 30.

Agoraki, M.-E. K., Delis, M. D., \& Pasiouras, F. (2011). Regulations, competition and bank risk-taking in transition countries. Journal of Financial Stability, 7(1), 38-48. http://dx.doi.org/ 10.1016/j.jfs.2009.08.002

Agusman, A., Cullen, G. S., Gasbarro, D., Monroe, G. S., \& Zumwalt, J. K. (2014). Government intervention, bank ownership and risk-taking during the Indonesian financial crisis. Pacific-Basin Finance Journal, 30(0), 114-131. http://dx.doi.org/10.1016/j.pacfin.2014.07.003

Altunbas, Y., Carbo, S., Gardener, E. P. M., \& Molyneux, P. (2007). Examining the Relationships between Capital, Risk and Efficiency in European Banking. European Financial Management, 13(1), 49-70. http://dx.doi.org/10.1111/j.1468-036X.2006.00285.x

Anderson, R. C., \& Fraser, D. R. (2000). Corporate control, bank risk taking, and the health of the banking industry. Journal of Banking \& Finance, 24(8), 1383-1398. http://dx.doi.org/10.1016/S0378-4266(99)00088-6

Angbazo, L. (1997). Commercial bank net interest margins, default risk, interest-rate risk, and off-balance sheet banking. Journal of Banking \& Finance, 21(1), 55-87. http://dx.doi.org/10.1016/S0378-4266(96)00025-8

Arellano, M., \& Bover, O. (1995). Another look at the instrumental variable estimation of error-components models. Journal of Econometrics, 68(1), 29-51. http://dx.doi.org/10.1016/0304-4076(94)01642-D

Ayuso, J., Pérez, D., \& Saurina, J. (2004). Are capital buffers pro-cyclical?: Evidence from Spanish panel data. Journal of Financial Intermediation, 13(2), 249-264. http://dx.doi.org/10.1016/S1042-9573(03)00044-5

Beck, T., Demirgüç-Kunt, A., \& Levine, R. (2006). Bank concentration, competition, and crises: First results. Journal of Banking \& Finance, 30(5), 1581-1603. http://dx.doi.org/10.1016/j.jbankfin.2005.05.010

Berger, A. N. (1995). The Relationship between Capital and Earnings in Banking. Journal of Money, credit and Banking, 27(2), 432-456.

Bessler, W., \& Nohel, T. (1996). The stock-market reaction to dividend cuts and omissions by commercial banks. Journal of Banking \& Finance, 20(9), 1485-1508. http://dx.doi.org/10.1016/S0378-4266(96)00004-0

Blum, J. (1999). Do capital adequacy requirements reduce risks in banking? Journal of Banking \& Finance, 23(5), 755-771. http://dx.doi.org/10.1016/S0378-4266(98)00113-7

Blundell, R., \& Bond, S. (1998). Initial conditions and moment restrictions in dynamic panel data models. Journal of Econometrics, 87(1), 115-143. http://dx.doi.org/10.1016/S0304-4076(98)00009-8

Boubakri, N., Cosset, J.-C., \& Saffar, W. (2013). The role of state and foreign owners in corporate risk-taking: Evidence from privatization. Journal of Financial Economics, 108(3), 641-658. http://dx.doi.org/ 10.1016/j.jfineco.2012.12.007

Boyd, J. H., \& De Nicoló, G. (2005). The Theory of Bank Risk-Taking and Competition Revisited. Journal of Finance, 60(3), 1329-1343. http://dx.doi.org/ 10.1111/j.1540-6261.2005.00763.x

Calem, P., \& Rob, R. (1999). The Impact of Capital-Based Regulation on Bank Risk-Taking. Journal of Financial Intermediation, 8(4), 317-352. http://dx.doi.org/10.1006/jfin.1999.0276

Chaibi, H., \& Ftiti, Z. (2015). Credit risk determinants: Evidence from a cross-country study. Research in International Business and Finance, 33, 1-16. http://dx.doi.org/ 10.1016/j.ribaf.2014.06.001

Cihák, M., \& Schaeck, K. (2007). Banking Competition and Capital Ratios. IMF Working Paper No. 07/216.

Deelchand, T., \& Padgett, C. (2009). The Relationship between Risk, Capital and Efficiency: Evidence from Japanese Cooperative Banks. ICMA Centre Discussion Papers in Finance DP2009-12.

Festić, M., Kavkler, A., \& Repina, S. (2011). The macroeconomic sources of systemic risk in the banking sectors of five new EU member states. Journal of Banking \& Finance, 35(2), 310-322. http://dx.doi.org/10.1016/j.jbankfin.2010.08.007 
Fraser, D. R., Madura, J., \& Weigand, R. A. (2002). Sources of Bank Interest Rate Risk. Financial Review, 37(3), 351-367. http://dx.doi.org/ 10.1111/0732-8516.00002

González, F. (2005). Bank regulation and risk-taking incentives: An international comparison of bank risk. Journal of Banking \& Finance, 29(5), 1153-1184. http://dx.doi.org/ 10.1016/j.jbankfin.2004.05.029

Haq, M., \& Heaney, R. (2012). Factors determining European bank risk. Journal of International Financial Markets, Institutions and Money, 22(4), 696-718. http://dx.doi.org/ 10.1016/j.intfin.2012.04.003

Hassan, M. K., Karels, G. V., \& Peterson, M. O. (1994). Deposit insurance, market discipline and off-balance sheet banking risk of large U.S. commercial banks. Journal of Banking \& Finance, 18(3), 575-593. http://dx.doi.org/10.1016/0378-4266(94)90010-8

Ho, S. J., \& Hsu, S.-C. (2010). Leverage, performance and capital adequacy ratio in Taiwan's banking industry. Japan and the World Economy, 22(4), 264-272. http://dx.doi.org/ 10.1016/j.japwor.2010.06.007

Hussain, M. E., \& Hassan, M. K. (2005). Basel Capital Requirements and Bank Credit Risk Taking In Developing Countries. Department of Economics and Finance Working Papers, 1991-2006, 34.

Iannotta, G., Nocera, G., \& Sironi, A. (2013). The impact of government ownership on bank risk. Journal of Financial Intermediation, 22(2), 152-176. http://dx.doi.org/10.1016/j.jfi.2012.11.002

Iwatsubo, K. (2007). Bank capital shocks and portfolio risk: Evidence from Japan. Japan and the World Economy, 19(2), 166-186. http://dx.doi.org/ 10.1016/j.japwor.2005.09.001

Jacques, K., \& Nigro, P. (1997). Risk-based capital, portfolio risk, and bank capital: A simultaneous equations approach. Journal of Economics and Business, 49(6), 533-547. http://dx.doi.org/10.1016/S0148-6195(97)00038-6

Jiménez, G., \& Saurina, J. (2006). Credit Cycles, Credit Risk, and Prudential Regulation. International Journal of Central Banking, 2(2), 65-98.

Jokipii, T., \& Milne, A. (2011). Bank capital buffer and risk adjustment decisions. Journal of Financial Stability, 7(3), 165-178. http://dx.doi.org/10.1016/j.jfs.2010.02.002

Kahane, Y. (1977). Capital Adequacy and the Regulation of Financial Intermediaries. Journal of Banking and Finance, 1(2), 207-218. http://dx.doi.org/10.1016/0378-4266(77)90007-3

Keeley, M. C. (1990). Deposit Insurance, Risk, and Market Power in Banking. The American Economic Review, 80(5), 1183-1200.

Kim, D., \& Santomero, A. M. (1988). Risk in Banking and Capital Regulation. Journal of Finance, 43, 1219-1233. http://dx.doi.org/10.1111/j.1540-6261.1988.tb03966.

Klomp, J., \& Haan, J. d. (2012). Banking risk and regulation: Does one size fit all? Journal of Banking \& Finance, 36(12), 3197-3212. http://dx.doi.org/ 10.1016/j.jbankfin.2011.10.006

Koehn, M., \& Santomero, A. M. (1980). Regulation of Bank Capital and Portfolio Risk. Journal of Finance, 35, 1235-1244. http://dx.doi.org/10.1111/j.1540-6261.1980.tb02206

Konishi, M., \& Yasuda, Y. (2004). Factors affecting bank risk taking: Evidence from Japan. Journal of Banking \& Finance, 28(1), 215-232. http://dx.doi.org/10.1016/S0378-4266(02)00405-3

Kwan, S., \& Eisenbeis, R. A. (1997). Bank Risk, Capitalization, and Operating Efficiency. Journal of Financial Services Research, 12, 117-131.http://dx.doi.org/ 10.1023/A:1007970618648

Laeven, L., \& Levine, R. (2009). Bank governance, regulation and risk taking. Journal of Financial Economics, 93(2), 259-275. http://dx.doi.org/ 10.1016/j.jfineco.2008.09.003

Lee, T.-H., \& Chih, S.-H. (2013). Does financial regulation affect the profit efficiency and risk of banks? Evidence from China's commercial banks. The North American Journal of Economics and Finance, 26, 705-724. http://dx.doi.org/ 10.1016/j.najef.2013.05.005

Levine, R., Caprio, G., \& Barth, J. (1999). Banking Systems Around the Globe: Do Regulation and Ownership Affect Performance and Stability? : The World Bank. http://dx.doi.org/10.1596/1813-9450-2325

Lin, S. L., Penm, J. H. W., Gong, S.-C., \& Chang, C.-S. (2005). Risk-based capital adequacy in assessing on insolvency-risk and financial performances in Taiwan's banking industry. Research in International Business and Finance, 19(1), 111-153. http://dx.doi.org/10.1016/j.ribaf.2004.10.006

Llewellyn, D. T. (2002). An analysis of the causes of recent banking crises. The European Journal of Finance, 8(2), 152-175. http://dx.doi.org/ 10.1080/13518470110071182 
Louzis, D. P., Vouldis, A. T., \& Metaxes, V. L. (2012). Macroeconomic and bank-specific determinants of non-performing loans in Greece: a comparative study of mortgage, business and consumer loan portfolios. Journal of Banking \& Finance, 36(4), 1012-1027. http://dx.doi.org/10.1016/j.jbankfin.2011.10.012

Mamatzakis, E., \& Bermpei, T. (2014). What drives investment bank performance? The role of risk, liquidity and fees prior to and during the crisis. International Review of Financial Analysis. http://dx.doi.org/ org/10.1016/j.irfa.2014.07.012

Naceur, S. B., \& Omran, M. (2011). The effects of bank regulations, competition, and financial reforms on banks' performance. Emerging Markets Review, 12(1), 1-20. http://dx.doi.org/ 10.1016/j.ememar.2010.08.002

Nkusu, M. (2011). Nonperforming Loans and Macrofinancial Vulnerabilities in Advanced Economies. IMF Working Paper 11/161.

Park, S., \& Peristiani, S. (2007). Are bank shareholders enemies of regulators or a potential source of market discipline? Journal of Banking \& Finance, 31(8), 2493-2515. http://dx.doi.org/ 10.1016/j.jbankfin.2006.10.025

Rime, B. (2001). Capital requirements and bank behaviour: Empirical evidence for Switzerland. Journal of Banking \& Finance, 25(4), 789-805. http://dx.doi.org/10.1016/S0378-4266(00)00105-9

Roy, A. (2008). Organization Structure and Risk Taking in Banking. Risk Management, 10(2), $122-134$. http://dx.doi.org/ 10.1057/palgrave.rm.8250043

Saunders, A., \& Wilson, B. (2001). An Analysis of Bank Charter Value and Its Risk-Constraining Incentives. Journal of Financial Services Research, 19(2-3), 185-195. http://dx.doi.org/10.1023/A:1011163522271

Shrieves, R. E., \& Dahl, D. (1992). The relationship between risk and capital in commercial banks. Journal of Banking \& Finance, 16(2), 439-457. http://dx.doi.org/10.1016/0378-4266(92)90024-T

Wagster, J. D. (1996). Impact of 1988 Basel Accord on international banks. Journal of Finance, 51(4), $1321-1346$. http://dx.doi.org/ 10.2307/2329396

Zhang, J., Jiang, C., Qu, B., \& Wang, P. (2013). Market concentration, risk-taking, and bank performance: Evidence from emerging economies. International Review of Financial Analysis, 30, 149-157. http://dx.doi.org/ 10.1016/j.irfa.2013.07.016

Zhang, Z.-y., Wu, J., \& Liu, Q.-f. (2008). Impacts of Capital Adequacy Regulation on Risk-taking Behaviors of Banking. Systems Engineering - Theory \& Practice, 28(8), 183-189. http://dx.doi.org/10.1016/S1874-8651(09)60035-1

\section{(cc) $\mathrm{Er}$}

This work is licensed under a Creative Commons Attribution 3.0 License. 